\title{
Evaluation of urine dipstick and cystoscopy in bovine enzootic haematuria
}

\section{Avaliação da fita reagente para urinálise e cistoscopia na hematúria enzoótica bovina}

\author{
Mariana Pavelski ${ }^{*}$; Rudiger Daniel Ollhoff²; Ivan Roque Barros Filho²; \\ Ivan Deconto²; Alexander Welker Biondo²; Peterson Triches Dornbusch ${ }^{2}$
}

\begin{abstract}
Enzootic bovine haematuria is mainly caused by the chronic ingestion of bracken fern and is still considered an important cause of economic losses in beef herds, particularly in large metropolitan areas of Brazil that are not suitable for agriculture (weak soil, steep hills). The aim of this paper was evaluate if there is a correlation between the degree of haematuria and the presence of lesions in the urinary bladder of cows with bovine enzootic haematuria $(\mathrm{BEH})$. We evaluated the bladder of twenty Nelore cows with bracken fern intoxication using a flexible endoscope to describe the lesions present and we performed a rapid urine test with a chemical multiple-reagent commercial strips (Combur test Roche ${ }^{\circledR}$ Swiss) to check the degree of haematuria; then we correlated both results with the Spearman statistical test. All cows presented lesions in their bladder walls and the urine was visually reddish and positive for haematuria in the strips. Urine dipstick has shown to correlate with bladder lesion number. In the bladders of the euthanised animals, multiple sub-mucosal reddish nodules and multiple ecchymotic haemorrhages were seen macroscopically, and one bladder had a larger tumour with a $3 \mathrm{~cm}$ diameter, which was determined to be a haemangioma by analysing the histopathology. We concluded that urine dipstick is a valuable device for bovine enzootic haematuria prognostic purposes and to evaluate the severity of lesions from the urinary bladder. Moreover, cystoscopy is an important diagnostic tool to assess bladder lesions in cattle. Further studies are necessary to evaluate the involvement of papillomaviruses and bladder tumour occurrence in these cows.
\end{abstract}

Key words: Beef herds, haematuria, urine dipstick

\section{Resumo}

Hematúria enzoótica bovina é causada principalmente pela ingestão crônica de samambaia e ainda é considerada uma importante causa de perdas econômicas em rebanhos de corte, especialmente em grandes áreas metropolitanas do Brasil que não são adequados para a agricultura (solo fraco, morros íngremes). O objetivo deste trabalho foi avaliar se há uma correlação entre o grau de hematúria e presença de lesões na bexiga urinária de vacas com hematúria enzoótica bovina (HEB). Avaliou-se a bexiga de vinte vacas Nelore com intoxicação por samambaia usando um endoscópio flexível para descrever as lesões presentes e foi realizado um teste de urina rápido por meio do uso de fitas químicas reagentes (Combur Roche ${ }^{\circledR}$ - Suiça) para verificar o grau de hematúria; então foram correlacionados ambos os resultados com o uso do teste estatístico de Spearman. Todas as vacas apresentavam lesões

\footnotetext{
${ }^{1}$ Discente de Doutorado do Programa de Pós Graduação em Ciências Veterinárias, Universidade Federal do Paraná, UFPR, Curitiba, Brasil. PR. E-mail: marimedvet@gmail.com

${ }^{2}$ Profs. Adjuntos da UFPR, Curitiba, PR, Brasil.E-mail: ollhoff@gmail.com; petriches@gmail.com; ivanbarf@ufpr.br; deconto@ ufpr.br; abiondo@illinois.edu

* Author for correspondence
} 
na parede da bexiga e a urina estava visualmente avermelhada, também o teste com as tiras foi positivo para hematúria. As fitas reagentes apresentaram uma correlação positiva com o número de lesões da bexiga. Nos bexigas dos animais que foi realizado eutanásia, vários nódulos avermelhados difusos pela submucosa e múltiplos pontos de equimose foram vistos macroscopicamente, e em uma bexiga havia um tumor maior com um diâmetro de 3 centímetros, o qual foi determinado como hemangioma por meio da análise histopatológica . Concluiu-se que as fitas reagentes para urinálise são uma ferramenta valiosa para avaliar a gravidade das lesões da bexiga urinária nos casos de hematúria enzoótica bovina. Além disso, a cistoscopia é uma importante ferramenta diagnóstica para avaliar lesões vesicais em bovinos. Mais estudos são necessários para avaliar o envolvimento de papilomavírus e ocorrência de tumor de bexiga nestas vacas.

Palavras-chave: Rebanhos bovinos, hematuria, fita reagente para urinálise

Enzootic haematuria in cattle is a severe noninfectious syndrome caused by prolonged ingestion of toxic principles of bracken fern (Pteridium aquilinum) (METRE; DIVERS, 2006). There is no predisposition for race or sex to disease development (MARÇAL, 2003). The BEH occurs when $P$. aquilinum is ingested in an amount less than $10 \mathrm{Kg}$ per day continuously during one or more years (TOKARNIA; DÖBEREINER; PEIXOTO, 2000). The main signals are intermittent haematuria, prostration, anaemia, emaciation, rarely incontinence, and later may cause death (FRANÇA; TOKARNIA; PEIXOTO, 2002). The diagnosis of the disease is made based on the presence of clinical manifestations of intoxication, detection of the presence of haematuria and the finding of the plant on the property (MARÇAL, 2003). The differential diagnosis includes diseases that can cause haematuria, such as cystitis and pyelonephritis (RADOSTITS et al., 2002); also, other diseases should be excluded, like haemolytic anaemia, septicaemic pasteurellosis, mycotoxicosis, haemoglobinuria post-partum, leptospirosis and babesiosis (BLOWEY; WEAVER, 2003; GILES; ANDREWS, 2004).

Bracken fern is distributed worldwide, and its initial ingestion is correlated with hunger (shortage of pasture) and overcrowded pastures (FRANÇA; TOKARNIA; PEIXOTO, 2002; RIET-CORRÊA et al., 2007).

Immunosuppressive, mutagenic and carcinogenic principles of P.aquilinum, such as ptaquiloside, have been correlated with papillomaviruses and bladder tumour occurrence (WOSIACKI et al., 2005; SOUTO et al., 2006; ROPERTO et al., 2008). In an experiment realised by Dias et al. (2012), of fifty bladder from cattle with $\mathrm{BEH}$, five presented neoplasms by histopathologic analysis and all five were positive to BPV-2, which was confirmed by PCR. These data support the hypothesis that BPV-2 may participate directly in the aetiology of HEB. Campo et al. (1992) supposes that the immunodepression activates the latent papillomavirus, causing premalignant lesions and the synergism between virus and co-carcinogenic factors results in tumour progression, although not in all of his experimental animals he could identify BPV. This reactivation can occur by immunosuppression caused by compounds of fern or physical trauma, manifested clinically by skin warts and bladder tumours (WOSIACKI et al., 2002).

A cancer model to explain mainly ptalquilosideinduced carcinogenicity was proposed on a molecular and cellular level by Australian researchers in 1999 (SHAHIN; SMITH; PRAKASH, 1999). Cytogenetic analysis of bracken fern grazing cattle also revealed chromosome fragility (PERETTI et al., 2007).

Nevertheless, some Brazilian farmers still produce cattle in pasture areas with high bracken fern prevalence, because these areas are frequently cheaper and located next to the main metropolitan regions. In an attempt to provide alternatives for these small cattle producers to live with bracken 
fern toxicity, several studies have been conducted in order to minimise the loss; for example, Oliveira, et al. (2008) studied phytotherapy to heal microhaematuria caused by chronic ingestion of bracken fern.

The evaluation of the bladder mucosa by endoscopy is useful to identify sources of bleeding, ulcerative lesions, tumours, surface mucosa characteristics, and the presence of ectopic structures, where cystoscopy facilitates diagnosis and makes it possible to give a more accurate prognosis based upon the findings (KASARI, 2000; FRANZ; WINTER; BAUMGARTNER, 2004).

The aim of this paper was evaluate if there is a correlation between the degree of haematuria evaluated by commercial multiple chemical -reagent strips (Combur test Roche ${ }^{\circledR}-$ Swiss) and the presence of lesions in the urinary bladder evaluated by cystoscopy.

Using a flexible endoscope (Veterinary videoendoscope $2000 \mathrm{~mm}$ large x 9mm diameter, Welch Allyn $\left.{ }^{\circledR}\right)$, we evaluated twenty Nelore cows with bracken fern intoxication. The diagnosis was based mainly on the clinical signs and a long history of the ingestion of bracken fern. The animals used were beef cattle from the same farm located in Parana state, with an age of about three years, who had eaten bracken fern continuously for at least one year before this study. We performed a physical examination of all animals; their temperature, pulse rate, colour of mucous membranes, cardiac rhythm and cardiac and lung sounds were checked. To perform the urine rapid test and cystoscopy, the animals were mechanically restrained and perineal stimulation was performed to make cows urinate naturally.

The urine was collected in a tube and evaluated with the strips (Combur $\left.{ }^{\circledR}\right)$. We differentiated the haematuria in crosses - (absence of blood) to ++++ (visible blood in urine) scale. In order to minimise the risks of contamination, the endoscope and vaginal speculum (Hauptner ${ }^{\circledR}$ - $16 \mathrm{~cm}$ for sheep and goats) were disinfected with $10 \%$ glutaraldehyde prior to cystoscopy. In addition, prior disinfection of the cow's external vaginal area was performed with $2 \%$ iodine, and the use of sterile gloves. A sheep vaginal speculum was used to identify the urethral ostium, which was locally desensitized by drops of lidocaine $2 \%$, facilitating cystoscopy after urination. The flexible endoscope was introduced through the urethra of the cows reaching the bladder; for better visualisation of the whole bladder they were insufflated with air. The total volume of the air was not measured and the air could escape through the urethra. Because the organ was insufflated with air, it promoted the visualisation of the whole organ; also visualisation with the flexible endoscope was chosen because it is possible to move and retroflect the machine to wherever necessary. The lesions were visually described by colour (light red, dark red) and salience of the bladder wall (flat, rough and stalked), and the number of lesions were described as rare when there was 1 to 3 lesions, moderate when there were 4 to 10 and countless with more than 10 lesions. Of the 20 adult cows assessed, we were not able to pass the endoscope in 7 , as the result of a tight urethra. The passage of the endoscope and the avoidance of the urethral recess was favoured by manually directing with a forefinger the endoscope. If during the whole process the animal defecates, an assistant deviated the faeces by hand. Eventually the speculum or the endoscope was contaminated and, if the endoscope was not entirely in the bladder, another cleaning and disinfection process was started.

Finally, two of the cows were selected at random to be euthanized. These animals did not have any specific signs apart from haematuria, lesions on the bladder and poor body condition. The owner of the farm did not allow more animals to be euthanized because of the economic losses, so the other animals of the study were sent to the abattoir. The euthanized cows had their bladders evaluated macroscopically and microscopically, and biopsies of the urinary bladder mucosa were taken and placed in $10 \%$ 
buffered formalin; some were embedded in paraffin, cut and stained with haematoxylin and eosin for histopathological examination.

In this study, it was not our aim to clarify the involvement of bovine papillomavirus with bladder lesions, but we did intend to perform further studies on this subject. The present study has been approved by the Ethics Committee on Animal Use, at the Pontifícia Universidade Católica do Paraná (PUCPR) (protocol number 323/2008).

To correlate both subjective data, the degree of the haematuria evaluated with the stickers and the number of lesions in the wall bladder evaluated by cystoscopy, we used the Spearman statistical correlation test, a non-parametric test. Dipstick reading, is an accurate (5-10 erythrocytes/ microliter urine) colorimetric method of visual interpretation, with a negligible interference factor ("intense jogging") for the parameter haemoglobin concerning cattle (COLOMBELI;FALKENBER, 2006) and was considered for subjective and nonparametric data. To apply the statistical test, we used the software GraphPad Prism ${ }^{\circledR}$ v.5 (GraphPad
Software Inc., La Jolla California, USA) with a confidence interval of $95 \%$ and an alpha of 0.05 .

In the physical examination, the changes we observed included pale mucous membranes and poor body condition. In the cystoscopy evaluation, we observed the lesions present in the bladder wall, which were classified by type (flat, rough, or stalked), colour (light and dark red) and number of lesions. In the visual macroscopic evaluation of the urine, all sample were reddish with no fibrinous masses or pus; only one sample presented with no red colouration. By the rapid urine test, we classified haematuria using the crosses - (absence of blood) to ++++ (visible blood in urine - 250 erythrocytes/ $\mu 1)$ scale. Only one animal presented lesions visualised by the cystoscopy with no haematuria on the stickers. These results can be observed in table 1. As the vast majority of animals had diffuse and countless lesions, we could not determine a pattern of localisation. Although other results of the dipstick analysis, such as $\mathrm{pH}$, protein and leukocytes, were available at the time of testing, they were not the aim of the present study and therefore not included in the results and discussion.

Table 1. Description of the endoscopic and urinalysis results of 13 chronic bracken fern intoxicated Nelore cows from a farm in Parana state, Brazil (Number of lesions: moderate 3-10, countless more than 10 lesions). (R 0.62/ P 0.0162)*

\begin{tabular}{lllll}
\hline Animal & Wall Lesion & Color of lesions & Number of lesions* & Dipstick haematuria scale* \\
\hline 01 & Rough & Dark and light red & Countless & ++++ \\
02 & Rough & Light red & Countless & ++ \\
03 & Rough & Light red & Countless & ++++ \\
04 & Rough & Light red & Moderate & + \\
05 & Rough & Light red & Countless & ++++ \\
06 & Rough & Light red & Countless & ++++ \\
07 & Flat & Dark and light red & Moderate & 0 \\
08 & Rough & Light red & Moderate & ++++ \\
09 & Rough & Dark and light red & Countless & ++++ \\
10 & Rough & Dark and light red & Countless & ++++ \\
11 & Rough & Dark and light red & Countless & ++++ \\
12 & Flat and Stalked & Dark and light red & Countless & ++++ \\
13 & Flat & Light red & Countless & ++++ \\
\hline
\end{tabular}

Source: Elaboration of the authors. 
In the bladders of the euthanised animals, multiple sub-mucosal reddish nodules and multiple ecchymotic haemorrhages were seen macroscopically; in one bladder there was a larger tumour with a $3 \mathrm{~cm}$ diameter, which was concluded to be a haemangioma by histopathological analysis (Figure 1). Peixoto et al. (2003) examining over 59 bladders from bracken fern intoxicated cattle, although noting that the association of different kinds of neoplasia were frequent, hemangiomas could appear solely. Applying the Spearman correlation test, we obtained high correlation between cystoscopy results and the degree of haematuria $(\mathrm{r}=0.6281)$ with the $\mathrm{P}$ value of 0.0162 . According to the authors knowledge, this was the first time that cystoscopy in chronically ill cows with bracken fern intoxication was realised in Brazil.

Even though other ferns (Cheilantes sieberi) have been associated with haematuria in cattle in Australia, Pteridium aquilinum is the main cause of chronic haematuria of cattle worldwide; this relationship has been experimentally proven at least since the experiences of Rosenberger and Heeschen (1960) and Rosenberger (1965). The eradication of the fern, mainly in steep terrain which was where the animals of this experiment were from, could be challenging, especially when working with small and poor farmers, who were not willing to or capable of investing a significant amount. The main objective for veterinary consultancy with regard to this condition is to minimise losses, which could be achieved by detecting clinical symptoms early and advising the early slaughter or culling, since the disease is still incurable, even with the recent efforts made (OLIVEIRA et al., 2008). Urinalysis rapid tests strips are used for this purpose, but there is no direct evidence that the urinalysis results correspond to major anatomical tumour alterations. This could now be stated associating cytoscopy.
Figure 1. Bladder of a euthanized cow with bovine enzootic haematuria. Multiple sub-mucosal reddish nodules, multiple ecchymosis haemorrhages and a larger tumour with a $3 \mathrm{~cm}$ diameter that was histologically diagnosed as a haemangioma were seen macroscopically.

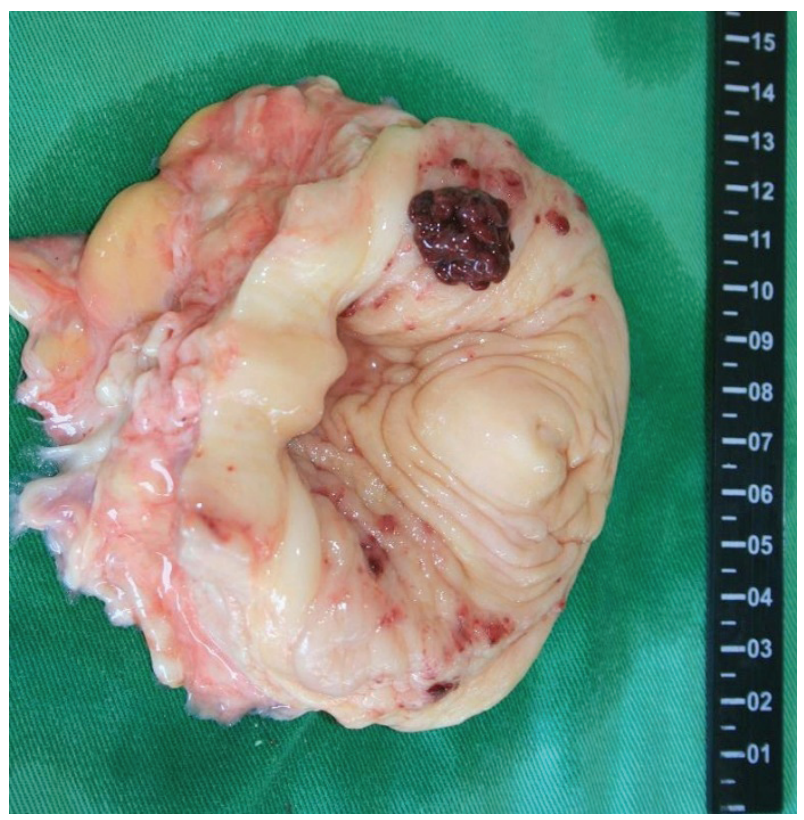

Source: Elaboration of the authors.

Because of the possible involvement of bovine papillomavirus (BPV-2) in the malignancy of bovine chronic haematuria, Wosiacki et al. (2005) suggested the development of a vaccine to ameliorate the clinical disease. Pathania et al. (2012) concluded by PCR that BPV-2 DNA is widely present in urine $(50 \%)$ and different types of urinary bladder, neoplastic or non-neoplastic lesions $(68,57 \%)$ in cows from a bovine enzootic haematuria endemic region.

We could not perform the cystoscopy in seven animals due to a tight urethra; we recommend trying to perform the exam with an endoscope with a smaller calibre $(5 \mathrm{~mm})$ to allow the access in most animals. Another limitation is that cystoscopy is only performed easily in females. The advantages of cystoscopy are the direct visualisation of mucosal lesions, secretion, colouring neoformation, visualisation of starter lesions and, most importantly, 
that it allows biopsies, facilitating the diagnosis (FRANZ; WINTER; BAUMGARTNER, 2004). When this tool is not accessible, we can apply the urine fast diagnostic strips (Combur ${ }^{\circledR}$ ) to identify the gravity of the present lesions, as we have shown the correlation between cystoscopy results and the degree of haematuria in the stickers. However, the dipsticks do not always show haematuria, for example in the animal where lesions were visualised by cystoscopy with no haematuria evident in the stickers. It is possible that the lesions were not bleeding during the urine exam, but the animal was included in the study because it presented a history of haematuria some days before. Another diagnostic tool that can be used is ultrasonography; this allows the evaluation of the thickness of the bladder wall, the lumen and the presence of neoformations, but does not allow the direct visualisation of the lesions and biopsies (HOQUE et al., 2002). Between cystoscopy and ultrasonography, we suggest performing cystoscopy, as the cost of both exams is similar, but cystoscopy provides you with more information and allows biopsies to be taken.

Most of the bladders that we evaluated had countless lesions and presented with rough wall on cystoscopy; these findings were similar to those of Di Loria et al. (2011). The macroscopic sub-mucosal reddish nodules, congestion and multiple ecchymotic haemorrhages were also seen by Somvanshi et al. (2011), who identified these as major injuries in the post-mortem evaluation of 236 urinary bladders. Only the number of lesions correlated with the dipstick haematuria scale. The relationship between a larger number of lesions and the probability of easier bleeding might be obvious, even though we presented the colour and the form of the lesions in order to describe exactly what we saw by cystoscopy. We believe that the difference in colour of the lesions differs between acute and chronic lesions, but we cannot confirm this because we did not perform any specific tests on each lesion.
By histopathological examination, the presence of a haemangioma was confirmed, as quoted by Carvalho, Naydan and Nunes (2009), and the endothelial-derived urinary bladder tumours are also quite common in $\mathrm{BEH}$, ranging from well differentiated cavernous haemangiomas to solid haemangiosarcomas. Some authors use the designation "haemangioendothelioma" for those vascular tumours that are histologically intermediate in appearance between a haemangioma and a conventional haemangiosarcoma (CARVALHO; NAYDAN; NUNES, 2009).

As cystoscopy was a relatively secure way to examine the urinary bladder, even though we could not pass all urethras, we suggest that this procedure should be adopted as routine by veterinary hospitals who examine cattle from bracken fern endemic regions. The visual evaluation and possibility of clinical follow-up is a main advantage of citoscopy, which would also facilitate the evaluation of treatment results encouraging further studies for the development of feasible therapeutic approaches. Finally, as bladder lesions were observed in all animals, the correlation between bladder lesions and microhaematuria could not be fully tested; therefore, future studies should be conducted in healthy animals and those with other diseases. Even though, a better classification of macrohematuria was achieved.

As conclusion, cystoscopy is an important diagnostic tool to assess bladder lesions in cattle. When this tool is not available, other ways to evaluate bladder haematuria is to use the rapid urine test; this is a valuable instrument for prognostic purposes and to evaluate the severity of bleeding lesions in the urinary bladder. Further studies are necessary to evaluate the involvement of papillomaviruses and bladder tumour occurrence in these cows.

In conclusion, dipstick may be used also as a prognostic rather than a diagnostic tool for chronic bracken fern intoxicated cattle. 


\section{References}

BLOWEY, R. W.; WEAVER, A. D. Toxicological disorders. In: Colour atlas of diseases and disorders of cattle. $2^{\text {nd }}$ ed. St. Louis: Mosby, 2003, p. 209-210.

CAMPO, M. S.; JARRETT, W. F. H.; O’NEIL, B. W.; SMITH, K. T. Association of bovine papillomavirus type 2 and bracken fern with bladder cancer in cattle. Cancer Research, Chicago, v. 52, n. 24, p. 6898-6904, 1992.

CARVALHO, T.; NAYDAN, D.; NUNES, T. Immunohistochemical evaluation of vascular urinary bladder tumours from cows with enzootic haematuria. Veterinary Pathology, Washington, v. 46, n. 2, p. 211221, 2009.

COLOMBELI,A.S. S.;FALKENBER, G. M. Comparison of product labelling's of two marks of reagent strips for the chemical examination of urine. Brazilian Journal of Pathology and Laboratory Medicine, Rio de Janeiro, v. 4, n. 2, p. 85-93, 2006.

DI LORIA, A.; PIANTEDOSI, D.; CORTESE, L.; ROPERTO, S.; URRARO, C.; PACIELLO, O.; GUCCIONE, J.; BRITTI, D.; CIARAMELLA, P. Clotting profile in cattle showing chronic enzootic haematuria (CEH) and bladder neoplasms. Research in Veterinary Science, Oxford, v. 93, n. 1, p. 331-335, 2011.

DIAS, J. D. C.; IGNACCHITI, M. D. C.; GIURIATO, P. G. G.; NUNES, L. C.; PEREIRA JUNIOR, O. S. Detecção do papilomavírus bovino tipo $2 \mathrm{em}$ bexigas de bovinos com hematúria enzoótica pela técnica de reação em cadeia de polimerase no sul do espírito santo, Brasil. Revista Brasileira de Medicina Veterinária, Rio de Janeiro, v. 34, n. 2, p. 146-151, 2012.

FRANÇA, T. N.; TOKARNIA, C. H.; PEIXOTO, P. V. Diseases determined by the radiomimetic principle of Pteridium aquilinum (Polypodiaceae). Pesquisa Veterinária Brasileira, Seropédica, v. 22, n. 3, p. 85-96, 2002.

FRANZ, S.; WINTER, P.; BAUMGARTNER, W. Cystoscopy in cattle-a valuable additional tool for clinical examination Acta Veterinaria Hungarica, Budapest, v. 52, n. 4, p. 423-438, 2004.

GILES, C. J.; ANDREWS, A. H. Major poisonings. In: ANDREWS, A. H.; BLOWEY, R. W.; BOYD, H. EDDY, R. G. (Ed.). Bovine medicine diseases and husbandry of cattle. Oxford: Blackwell Science, 2004. p. 946-947.

HOQUE, M.; SOMVANSHI, R.; SINGH, G. R.; MOGHA, I. V. Ultrasonographic evaluation of urinary bladder in normal, fern fed and enzootic bovine haematuria-affected cattle. Journal of Veterinary Medicine Series A, Berlin, v. 49, n. 8, p. 403-407, 2002.
KASARI, T. R. Clinical examination of urinary system. In: RADOSTITS, O. M.; MAYHEW, J. I. G.; HOUSTON, D. M. Clinical examination and diagnosis in veterinary. Rio de Janeiro: Guanabara Koogan, 2000. p. 373-38.

MARÇAL, W. S. A intoxicação por samambaia em bovinos criados no Estado do Paraná. Semina Ciências Agrárias, Londrina, v. 24, n. 1, p. 197-208, 2003.

METRE, D.; DIVERS, T. J. Diseases of the kidney In: SMITH, B. P. Large animal internal medicine. São Paulo: Manole, 2006. p. 862-863.

OLIVEIRA, R. A. M.; KLOSTER, F. S.; BUENO, E. F.; MOLLI, C. E.; POSSAMAI, A. P.; CIRIO, S. M.; ROCHA, R. M.; OLLHOFF, R. D. Could phytotherapy heal microhematuria caused by chronic ingestion of Pteridium a quilinum? In: JUBILEE WORLD BUIATRICS CONGRESS, 25., 2008, Budapest. Procedings... Budapest: Kiadó Publisher, v. 130, 2008. p. 28-28.

PATHANIA, S.; DHAMA, K.; SAIKUMAR, G.; SHAHI, S.; SOMVANSHI, R. Detection and quantification of bovine papilloma virus type 2 (bpv-2) by real-time PCR in urine and urinary bladder lesions in enzootic bovine haematuria (EBH)-affected cows. Transboundary and Emerging Diseases, Berlin, v. 59, n. 1, p. 79-84, 2012.

PEIXOTO, P. V.; NASCIMENTO FRANÇA, T.; BARROS, C. S. L.; TOKARNIA, C. H. Histopathological aspects of bovine enzootic hematuria in Brazil Pesquisa Veterinária Brasileira, Seropédica, v. 23, n. 2, p. 65-81, 2003.

PERETTI, V.; CIOTOLA, F.; ALBARELLAS, R. V.; DI MEO, G. P.; IANNUZZI, L.; ROPERTO, F.; BARBIERI, V. Chromosome fragility in cattle with chronic enzootic haematuria. Mutagenesis, Los Angeles, v. 22, n. 5, p. 317-320, 2007.

RADOSTITS, O. M.; GAY, C. C.; BLOOD, D. C.; HINCHCLIFF, K. W. Diseases caused by toxins from plants, fungi, cyanophytes, clavibactéria and poisons tick and vertebrate animals. In: Veterinary clinic - a treaty of diseases of cattle, sheep, pigs, goats and horses. 9. ed. Rio de Janeiro: Guanabara Koogan, 2002. p. 14721547.

RIET-CORRÊA, F.; SCHILD, A. L.; LEMOS, R. A. A.; BORGES, J. R. J. Diseases of ruminants and horses. Santa Maria: Palotti, 2007. v. 2, p. 173-176.

ROPERTO, S.; BRUN, R.; PAOLINI, F.; URRARO, C.; RUSSO, V.; BORZACCHIELLO, G.; RASO, U. P. C.; RIZZO, C.; ROPERTO, F.; VENUTI, A. Detection of bovine papillomavirus type 2 in the peripheral blood of cattle with urinary bladder tumours: possible biological role. Journal of General Virology, London, v. 89, n. 12, p. 3027-3033, 2008. 
ROSENBERGER, G. Längere aufnahme von adlerfarn (Pteris aquilina) - die ursache der chronischen vesikalen haematuria des rindes. Wiener Tierärztliche Monatsschrift, v. 52, n. 5, p. 415-421, 1965.

ROSENBERGER, G.; HEESCHEN, W. Adlerfan (Pteris aquilina) - die Ursache des sogenannten stallrotes der rinder (Haematuria vesicalis bovis chronica). Deutsche TierärztlicheWochenschrift, v. 67, n. 8, p. 201-208, 1960.

SHAHIN, M.; SMITH, B. L.; PRAKASH, A. S. Bracken carcinogens in the human diet. Mutation Research, Amsterdam, v. 443, n. 1-2, p. 69-79, 1999.

SOMVANSHI, R.; PATHANIA, S.; NAGARAJAN, N.; PANGTY, K.; KUMAR, P. Pathological study of nonneoplastic urinary bladder lesions in cattle and buffaloes: a preliminary report. Tropical Animal Health Production, Edinburgh, v. 44, n. 4, p. 855-861, 2011.
SOUTO, M. A. M.; KOMMERS, G. D.; BARROS, C. S. L.; RECH, R. R.; PIAZER, J. V. M. Neoplasms of the bladder associated with bovine enzootic haematuria. Ciência Rural, Santa Maria, v. 36, n. 5, p. 1647-1650, 2006.

TOKARNIA, C. H.; DÖBEREINER, J.; PEIXOTO, P. V. Plantas de ação radiomimética. In:__. Plantas tóxicas do Brasil. Rio de Janeiro: Helianthus, 2000. p. 178-187.

WOSIACKI, S. R.; BARREIRO, M. A. B.; ALFIERI, A. F.; ALFIERI, A. A. Semi-nested PCR for detection and typing of bovine Papilloma virus type 2 in urinary bladder and whole blood from cattle with enzootic haematuria. Journal of Virological Methods, Amsterdam, v. 126, n. 1-2, p. 215-219, 2005.

WOSIACKI, S. R.; REIS, A. C. F.; ALFIERI, A. F.; ALFIERI, A. A. Papilomavírus bovino tipo 2 na etiologia da hematúria enzoótica bovina. Semina: Ciências Agrárias, Londrina, v. 23, n. 1, p. 121-130, 2002. 